\title{
Pythium Species Associated with Damping-off of Pea in Certified Organic Fields in the Columbia Basin of Central Washington
}

Ana Vida C. Alcala, Washington State University Mount Vernon NWREC, Mount Vernon 98273-4768; Timothy C. Paulitz and Kurtis L.
Schroeder, United States Department of Agriculture-Agricultural Research Service (USDA-ARS), Pullman, WA 99164-6430; Lyndon D.
Porter, USDA-ARS, Prosser, WA 99350-8694; and Michael L. Derie and Lindsey J. du Toit, Washington State University Mount Vernon NWREC

\begin{abstract}
Alcala, A. V. C., Paulitz, T. C., Schroeder, K. L., Porter, L. D., Derie, M. L., and du Toit, L. J. 2016. Pythium species associated with damping-off of pea in certified organic fields in the Columbia Basin of central Washington. Plant Dis. 100:916-925.

Organic vegetable production accounted for $19 \%$ of the total organic acreage in Washington State in 2013, with 1,700 ha of certified organic vegetable pea. However, production is challenged constantly with the threat of poor emergence after planting due to damping-off caused by Pythium spp. A survey of Pythium spp. in organic vegetable production areas of the semiarid Columbia Basin of central Washington was carried out in fall 2009 to identify species associated with damping-off during early spring planting. Of 305 isolates baited from soil sampled from 37 certified organic fields, 264 were identified to 16 Pythium spp. by sequencing the internal transcribed spacer region of ribosomal DNA. A soil DNA-CFU regression curve was developed using real-time quantitative polymerase chain reaction assays for each of the three predominant

pathogenic species (Pythium abappressorium, the P. irregulare complex, and $P$. ultimum var. ultimum) found in soil sampled from the 37 fields. The $P$. irregulare complex, $P$. abappressorium, and $P$. ultimum var. ultimum were detected in 57, 78, and $100 \%$ of the fields sampled, respectively. A regression analysis was used to determine that $P$. ultimum var. ultimum ranged from 14 to $332 \mathrm{CFU} / \mathrm{g}$ of soil in the 37 fields, the $P$. irregulare complex ranged from 25 to $228 \mathrm{CFU} / \mathrm{g}$ of soil, and $P$. abappressorium DNA was below the quantifiable limit. In summary, P. ultimum var. ultimum was the most prevalent pathogenic Pythium sp. detected in certified organic fields in the semiarid Columbia Basin of central Washington but multiple Pythium spp. may be associated with damping-off in cool and wet, early spring planting conditions.
\end{abstract}

Organic crop production in Washington State has expanded greatly over the past decade (Granatstein et al. 2005). In 2013, there were 712 certified organic farms in Washington and approximately 34,000 ha devoted to certified organic production (Kirby and Granatstein 2014). A majority of these organic hectares are located in the semiarid, irrigated area of central Washington, referred to as the Columbia Basin, which is characterized primarily by large-scale agricultural production (Kirby and Granatstein 2014). In 2013, organic vegetable production comprised $19 \%$ of the total organic acreage in Washington (Kirby and Granatstein 2014). Pea (Pisum sativum L.) is a vegetable crop grown widely in Washington, with 1,700 ha devoted to organic pea production in 2013 out of a total 6,600 ha of organic vegetable production in the state. Organic processing-pea crops accounted for $\$ 4.2$ million in sales and ranked second after sweet corn among organic vegetables grown in Washington (Granatstein and Kirby 2010; Kirby and Granatstein 2009).

The genus Pythium consists of many species that are important plant pathogens (Hendrix and Campbell 1973). At present, there are approximately 280 legitimate Pythium spp. and varieties listed

Present address of K. L. Schroeder: Department of Plant, Soil and Entomological Sciences, University of Idaho, Moscow 83844-2339.

Corresponding author: L. J. du Toit; E-mail: dutoit@wsu.edu

This project was supported by the Department of Plant Pathology (PPNS number 0691); the College of Agricultural, Human, and Natural Resource Sciences; the Agricultural Research Center (Hatch Project number WRN05595); and the Center for Sustaining Agriculture and Natural Resources BIOAg program at Washington State University.

*The $\boldsymbol{e}$-Xtra logo stands for "electronic extra" and indicates that one supplementary figure and one supplementary table are published online.

Accepted for publication 16 November 2015.

http://dx.doi.org/10.1094/PDIS-07-15-0774-RE

(c) 2016 The American Phytopathological Society in MycoBank (http://www.mycobank.org/), a majority of which are recognized soilborne pathogens. Many pathogenic species are ubiquitous and can infect a diversity of agricultural crops (Agrios 2005; Martin and Loper 1999). Pythium spp. are necrotrophic, early colonizers, and opportunistic plant pathogens. They can infect vulnerable and stressed plants, particularly immature succulent tissues of germinating seed, feeder roots, and seedling stems, leading to pre- and postemergence damping-off (Agrios 2005; Hendrix and Campbell 1973; Martin and Loper 1999). Infected plants may result in poor plant stands, reduced plant vigor, and, potentially, significant yield losses (Cook 1992; Cook et al. 1987; Oyarzun 1993).

Surveys of Pythium spp. in soils have demonstrated that multiple species commonly coexist, including pathogenic and nonpathogenic species (Abad et al. 1994; Broders et al. 2007; Paulitz and Adams 2003). In a survey by Paulitz and Adams (2003) of 80 wheat fields in eastern Washington, approximately $30 \%$ of the Pythium isolates were of nonpathogenic species. Likewise, multiple pathogenic Pythium spp. can be associated with damping-off within the same field (Broders et al. 2007, 2009; Campion et al. 1997). Therefore, accurate identification of Pythium spp. is imperative for understanding the etiology of outbreaks of damping-off, and is a cornerstone to the development of effective management strategies (Lévesque 2001).

Some Pythium spp., such as Pythium ultimum, have a wide host range, while others infect a limited number of plant species (Augspurger 2007; Hendrix and Campbell 1973; Martin 1992). The ability of each species to infect plants is dictated by recognition of the host as well as the presence of environmental factors that favor disease development (Park 1963). Soil moisture and temperature have a great influence on the growth and capacity of Pythium spp. to incite disease (Hendrix and Campbell 1973; Martin and Loper 1999). In general, Pythium spp. are more prevalent in fields with greater soil moisture content (at or above field capacity) than drier soils (Cook 2002; Rao et al. 1978). Some species are favored by cool soil temperatures $\left(5\right.$ to $\left.10^{\circ} \mathrm{C}\right)$, such as $P$. ultimum var. ultimum and $P$. irregulare, while others thrive in warmer soils (as warm as 25 to $30^{\circ} \mathrm{C}$ ), such as $P$. aphanidermatum (Hendrix and Campbell 1973; Hershman 1986; van der Plaats-Niterink 1981). Temperature can also affect host susceptibility and seed exudation. 
For example, planting seed in soil $<10^{\circ} \mathrm{C}$ slowed seed germination compared with germination and exudation in soil at 22 to $30^{\circ} \mathrm{C}$; however, seed exudation lasted only $18 \mathrm{~h}$ at the warmer soil temperatures compared with $48 \mathrm{~h}$ at $10^{\circ} \mathrm{C}$ (Martin and Loper 1999; Nederhoff 2000; Short and Lacy 1976). Conditions that favor extended periods of seed exudation also can favor greater levels of pathogen spore germination and seedling decay (Short and Lacy 1976).

Pythium-induced damping-off is one of the major constraints in production of organic vegetable crops in Washington, particularly for vegetables planted early in the season such as pea (Alcala and du Toit 2009). Early spring planting of pea crops in the Columbia Basin not only exposes the seed to cool and moist soil conditions but the water used to irrigate crops in this region also is cold $\left(<10^{\circ} \mathrm{C}\right)$, contributing to conditions that slow seed germination and are highly conducive to damping-off (Agrios 2005; Cook 2002; Hendrix and Campbell 1973). However, early planting of organic processing-pea crops in the Columbia Basin is difficult for growers to avoid because of the necessity of planting early to (i) reduce weed competition, particularly from nightshade species common in the area (e.g., Solanum nigrum L.) which produce berries toxic to humans and animals, and which cannot be separated readily from pea by the processing equipment; (ii) harvest and process organic pea crops prior to conventional pea crops to avoid having to clean the processing equipment between conventional and organic crops; (iii) double-crop pea and sweet corn in the limited duration of the growing season (March to October) in this temperate region; and (iv) allow for robust pod set because warm summer temperatures of this region will result in flower abortion (Alcala and du Toit 2009; Mansour et al. 1984; Miller and Parker 2006).

The significant losses to damping-off in organic vegetable production and the need for effective management strategies warranted investigation of the primary causal Pythium spp. during early spring planting conditions in certified organic fields in the Columbia Basin. Previous studies have investigated Pythium spp. diversity in Washington soils in wheat production areas of eastern Washington (Chamswarng and Cook 1985; Paulitz and Adams 2003), and in soils in organic and conventional apple (Malus domestica Borkh.) orchards in the Columbia Basin (Mazzola et al. 2002). However, dryland cereal production in eastern Washington is very different from agriculture in the semiarid, irrigated Columbia Basin of central Washington, and perennial orchard systems may have different plant-pathogenic soil microflora than annual vegetable cropping systems in irrigated agriculture in the Columbia Basin. Therefore, the objectives of this study were to (i) survey Pythium spp. present in certified organic fields in the Columbia Basin that are commonly used for vegetable production, particularly pea production; and (ii) quantify inoculum levels of the three most prevalent and pathogenic Pythium spp. in soil sampled from certified organic fields in the Columbia Basin (Alcala 2013).

\section{Materials and Methods}

Fields surveyed. In October 2009, 37 fields used for certified organic vegetable production in the Columbia Basin were surveyed for Pythium spp. The fields were selected based on vegetable cropping history (i.e., planted to pea or sweet corn in the previous 5 years) and to represent the northern region (17 fields) between Warden (46.968 $\mathrm{N}$ and $-119.040 \mathrm{~W}$ ) and Ephrata, WA (47.314 N and -119.554 W), central region ( 5 fields) between Warden and Eltopia, WA (46.459 $\mathrm{N}$ and $-119.017 \mathrm{~W}$ ), and southern region (15 fields) between Eltopia and Paterson, WA (45.939 N and $-119.603 \mathrm{~W}$ ) of the Columbia Basin (Table 1; Supplementary Table S1). Soil samples were collected from each field in October, when most of the fields were either fallow or planted to a cover crop. All of the fields surveyed were irrigated using center pivots, and individual fields ranged from 15 to 50 ha.

Soil sampling. Sampling of full center-pivot fields was done along each of four transects in a grid pattern. Samples for half-circle fields were collected along four parallel transects across the half-circle. Soil sampling was done by four people in each field, with each person collecting 20 soil cores/transect to a depth of $15 \mathrm{~cm}$ using a 2.5 -cm-diameter soil probe. The soil cores for each transect were pooled and mixed thoroughly, and a subsample was stored at $-20^{\circ} \mathrm{C}$ to be used to quantify selected Pythium spp. using real-time quantitative polymerase chain reaction (PCR) assays (described below). The rest of the soil was pooled for the four transects in a field and mixed thoroughly, and a 500-g subsample was sent to Soiltest Farm Consultants, Inc. (Moses Lake, WA) for nutrient analysis. The soil from each field was also used for baiting Pythium spp., as described below. At the time of sampling, soils were placed in a cooler with ice for transport to a cold-storage facility $\left(4 \pm 2{ }^{\circ} \mathrm{C}\right)$ at the Washington State University (WSU) Pullman campus.

Isolation and baiting. Two methods were used for baiting Pythium spp. from the soil samples. Grass leaf baiting was done based on the method described by Paulitz and Adams (2003). A 20 -g soil sample from each field was placed in a 15 -cm-diameter petri plate and moistened to field capacity with 3 to $5 \mathrm{ml}$ of tap water. Plates were incubated at room temperature $\left(22 \pm 2^{\circ} \mathrm{C}\right)$ for 24 to $48 \mathrm{~h}$. Distilled water $(10 \mathrm{ml})$ was added to each plate, and five grass clippings of Poa pratensis L., cut to about $2.5 \mathrm{~cm}$ long and sterilized by autoclaving at $1.1 \mathrm{~kg} / \mathrm{cm}^{2}(15 \mathrm{psi})$ and $121^{\circ} \mathrm{C}$ for $20 \mathrm{~min}$, were floated on the water in each plate. After 24 to $36 \mathrm{~h}$, the grass clippings were removed, blotted dry on sterilized paper towels, and plated on a Pythium selective agar medium (PSM; Mircetich and Kraft 1973). After 24 to $36 \mathrm{~h}$, emerging hyphal tips from the grass leaves were transferred to plates of water agar (WA). Hyphal growth patterns on WA were observed microscopically to select and isolate Pythium spp. A pure culture of each isolate was maintained on WA and stored at $4{ }^{\circ} \mathrm{C}$. For long-term storage, a WA block $\left(1 \mathrm{~cm}^{3}\right)$ colonized by the Pythium isolate was placed in a glass vial containing sterilized water and four sterilized hemp seed (HBD International Inc., Brentwood, $\mathrm{TN}$ ), and stored at room temperature.

Pythium spp. were also baited from each soil sample based on the method described by Broders et al. (2009). A subsample of approximately $500 \mathrm{~g}$ of soil from each field was placed in each of two 10 -cm-diameter pots, saturated with tap water for $24 \mathrm{~h}$, and then drained. The saturated soil was incubated for 14 days at $14^{\circ} \mathrm{C}$ with a photoperiod of $12 \mathrm{~h}$ /day in a growth chamber. Pythium spp. were baited from the soil by planting pregerminated seed of 'Chase' sweet corn (Monsanto Vegetable Seeds, St. Louis, MO) in one pot and of 'Tonic' pea (Brotherton Seed Co., Inc., Moses Lake, WA) in the other pot. Germination of the pea and sweet corn seed was initiated by wrapping the seed in a moist paper towel at room temperature for 3 to 5 days until the radicle was about $2.5 \mathrm{~cm}$ long. Five germinated seeds of each species were planted in the appropriate pot and maintained in a growth chamber at $10^{\circ} \mathrm{C}$ by night and $15^{\circ} \mathrm{C}$ by day with a photoperiod of $12 \mathrm{~h} /$ day to mimic the cold soil conditions of early spring planting in the Columbia Basin. The plants were irrigated with cold water stored in the growth chamber, mimicking the cold water used to irrigate fields in the Columbia Basin. Five days after planting, the pots were flooded with water for $24 \mathrm{~h}$ to promote damping-off from Pythium spp. that might be present in the soil. Four days after flooding, seed and seedlings in each of the pots were removed and washed, and the roots were cut off and blotted dry on sterilized paper towels. Root sections were plated onto PSM and incubated at $22 \pm 2^{\circ} \mathrm{C}$ for 24 to $36 \mathrm{~h}$, prior to making hyphal tip transfers of the emerging mycelium onto WA plates. Pure cultures of the isolates were maintained on WA and kept at $4{ }^{\circ} \mathrm{C}$ for species identification. Isolates were stored for the long term in sterilized water with hemp seed, as described above.

Pythium spp. identification. Pythium isolates obtained from soil samples using grass leaves or by pea and sweet corn root baiting were identified to species initially by microscopic examination of morphological features (van der Plaats-Niterink 1981). A culture of each isolate was grown in a petri plate containing pond water (from a pond in Reaney Park, Pullman, WA) that had been sterilized at $1.1 \mathrm{~kg} / \mathrm{cm}^{2}$ and $121^{\circ} \mathrm{C}$ for $20 \mathrm{~min}$. Five sterilized grass leaf clippings were floated on the water in each plate, and the plates kept on a laboratory bench for 24 to $36 \mathrm{~h}$ at room temperature. When mycelial growth became visible, the grass clippings were removed and a slide mount was prepared for microscopic examination of sporangia, oospores, antheridia, and oogonia characteristics.

DNA extraction and sequencing. To verify the species of the Pythium isolates, the internal transcribed spacer (ITS) region of the 
ribosomal DNA (rDNA) of each of the isolates was sequenced using the method described by Paulitz and Adams (2003). Each isolate was grown in potato dextrose broth (PDB) in petri plates for 5 to 14 days based on when at least three-quarters of the plate was covered with mycelial growth. Mycelium was removed from the PDB and excess liquid drained. The mycelium was then washed twice with sterilized distilled water, drained, and placed in a 1.7-ml Eppendorf tube. Harvested mycelia were stored at $-20^{\circ} \mathrm{C}$ until used for DNA extraction.

DNA was extracted from mycelium of each isolate using the FastDNA Kit (MP Biomedicals, Santa Ana, CA) along with the Fast Prep FP120 cell disruptor (American Instrument Exchange, Inc.,
Havervill, MA) following the manufacturer's protocol. PCR amplification of the ITS region was done as described by Schroeder et al. (2006), using the primers UNUP18S42 (5'-CGTAACAAGGTTTC CGTAGGTGAAC-3') and UN-LO28S22 (5'GTTTCTTTTCCTCC GCTTATTAATATG-3') (Bakkeren et al. 2000). The reaction mixture contained $2 \mu \mathrm{l}$ of DNA template, $6 \mu \mathrm{l}$ of $5 \times$ buffer, $1.5 \mathrm{mM} \mathrm{MgCl}_{2}$, $0.2 \mathrm{mM}$ each of the four dNTPs, 10 pmol of each of the primers, and $1.25 \mathrm{U}$ of Taq polymerase (Invitrogen Life Technologies, Grand Island, NY) in a total volume of $30 \mu \mathrm{l}$. Amplification of DNA was carried out using a PTC-200 Peltier thermal cycler (MJ Research, Reno, NV) with the following program: 3 min of initial denaturation

Table 1. Isolates of 16 Pythium spp. baited from soil sampled from 37 certified organic fields in the Columbia Basin of Washington

\begin{tabular}{|c|c|c|c|c|c|}
\hline \multirow[b]{2}{*}{ Species, isolate ${ }^{b}$} & \multirow[b]{2}{*}{ Field code ${ }^{c}$} & \multirow[b]{2}{*}{ Baiting method ${ }^{\mathbf{d}}$} & \multicolumn{3}{|c|}{ ITS rDNA GenBank submission ${ }^{a}$} \\
\hline & & & Homology (\%) & Closest matching accession & Submitted sequence \\
\hline \multicolumn{6}{|c|}{ Pythium abappressorium } \\
\hline B3-94 & 22 & Grass leaves & 99 & HQ643408.2 & KP862934 \\
\hline B13-168 & 34 & Pea & 98 & HQ643408.2 & $\ldots$ \\
\hline B12-160 & 20 & Corn & 96 & HQ643408.2 & $\ldots$ \\
\hline B11-97 & 20 & Corn & 97 & HQ643408.2 & $\ldots$ \\
\hline B11-111 & 3 & Pea & 96 & HQ643408.2 & $\ldots$ \\
\hline B10-16 & 27 & Corn & 96 & HQ643408.2 & $\ldots$ \\
\hline B10-2 & 27 & Corn & 96 & HQ643408.2 & KP862935 \\
\hline B11-86 & 11 & Corn & 99 & HQ643408.2 & $\ldots$ \\
\hline \multicolumn{6}{|l|}{ P. adhaerens } \\
\hline B3-81 & 1 & Grass leaves & 99 & AY598619.2 & $\ldots$ \\
\hline B3-86 & 37 & Grass leaves & 99 & AY598619.2 & $\ldots$ \\
\hline B2-57 & 10 & Grass leaves & 99 & AY598619.2 & KP862936 \\
\hline B3-87 & 10 & Grass leaves & 99 & AY598619.2 & $\ldots$ \\
\hline B1-35 & 37 & Grass leaves & 99 & AY598619.2 & $\ldots$ \\
\hline B2-52 & 23 & Grass leaves & 99 & AY598619.2 & $\ldots$ \\
\hline B3-66 & 37 & Grass leaves & 99 & AY598619.2 & $\ldots$ \\
\hline B1-10 & 25 & Grass leaves & 99 & AY598619.2 & KP862937 \\
\hline B3-67 & 10 & Grass leaves & 99 & AY598619.2 & $\ldots$ \\
\hline \multicolumn{6}{|l|}{ P. apiculatum } \\
\hline B3-69 & 9 & Grass leaves & 97 & HQ643443.2 & KP862938 \\
\hline B5-62 & 20 & Grass leaves & 96 & HQ643443.2 & KP862939 \\
\hline B1-16 & 3 & Grass leaves & 99 & HQ643443.2 & $\ldots$ \\
\hline \multicolumn{6}{|l|}{ P. aristosporum } \\
\hline B4-29 & 12 & Grass leaves & 100 & AY598627.2 & KP862940 \\
\hline B10-38 & 34 & Corn & 99 & AY598627.2 & KP862941 \\
\hline \multicolumn{6}{|l|}{ P. camurandrum } \\
\hline B8-104 & 26 & Grass leaves & 99 & HQ643481.1 & KP862942 \\
\hline \multicolumn{6}{|l|}{ P. carolinianum } \\
\hline B12-118 & 17 & Corn & 99 & HQ643484.1 & KP862943 \\
\hline B5-47 & 2 & Grass leaves & 99 & HQ643484.1 & KP862944 \\
\hline B5-45 & 2 & Grass leaves & 99 & HQ643484.1 & $\ldots$ \\
\hline B2-51 & 14 & Grass leaves & 99 & HQ643484.1 & $\ldots$ \\
\hline \multicolumn{6}{|l|}{ P. catenulatum } \\
\hline B9-157 & 7 & Grass leaves & 98 & AY598675.2 & KP862945 \\
\hline B3-88 & 37 & Grass leaves & 99 & AY598675.2 & KP862946 \\
\hline \multicolumn{6}{|l|}{ P. dissotocum } \\
\hline B4-4 & 9 & Grass leaves & 99 & AY598634.2 & $\ldots$ \\
\hline B4-5 & 9 & Grass leaves & 99 & AY598634.2 & $\ldots$ \\
\hline B3-84 & 20 & Grass leaves & 99 & AY598634.2 & $\ldots$ \\
\hline B5-59 & 20 & Grass leaves & 99 & AY598634.2 & $\ldots$ \\
\hline B1-32 & 30 & Grass leaves & 99 & AY598634.2 & KP862947 \\
\hline B4-2 & 6 & Grass leaves & 99 & AY598634.2 & $\ldots$ \\
\hline B2-49 & 34 & Grass leaves & 99 & AY598634.2 & KP862948 \\
\hline B3-79 & 34 & Grass leaves & 99 & AY598634.2 & $\begin{array}{c}\ldots \\
\text { (continued on next page) }\end{array}$ \\
\hline $\begin{array}{l}\text { a GenBank seque } \\
\text { isolates/species } \\
\text { the survey. }\end{array}$ & $\begin{array}{l}\text { test homolog } \\
\text { aited in this su }\end{array}$ & $\begin{array}{l}\text { he internal transcri } \\
\text { were submitted to } C\end{array}$ & $\begin{array}{l}\text { acer (ITS) riboso } \\
\text { nk, except for } P .\end{array}$ & $\begin{array}{l}\text { DNA (rDNA) sequence for tha } \\
\text { randrum as only one isolate of }\end{array}$ & $\begin{array}{l}\text { isolate. Sequences of two } \\
\text { iis species was obtained in }\end{array}$ \\
\hline $\begin{array}{l}\text { b Pythium spp. id } \\
\text { region of rDNA }\end{array}$ & $\begin{array}{l}\text { ased on morp } \\
\text { d by Bakkeren }\end{array}$ & $\begin{array}{l}\text { ical characterizatic } \\
(2000) \text {. }\end{array}$ & ulitz and Adams & van der Plaats-Niterink 1981) & and sequencing the ITS \\
\hline c Details of the 3 & anic fields are & ibed in Supplemen & able S1. & & \\
\hline
\end{tabular}


at $94^{\circ} \mathrm{C}$ for $3 \mathrm{~min}$; followed by 30 cycles of $45 \mathrm{~s}$ at $92^{\circ} \mathrm{C}, 45 \mathrm{~s}$ at the annealing temperature of $60^{\circ} \mathrm{C}$, and $60 \mathrm{~s}$ at $72^{\circ} \mathrm{C}$; and a final extension step of $10 \mathrm{~min}$ at $72^{\circ} \mathrm{C}$. The PCR products were separated on 1.0 or $1.5 \%$ agarose gels along with a 100-bp molecular weight DNA ladder (Invitrogen Life Technologies) to ensure the presence of appropriate-sized amplified DNA prior to sequencing. The DNA concentration was determined using a NanoDrop 1000 (Thermo
Scientific Co., Wilmington, DE) or by Qubit fluorometric quantification using the Quant-iT dsDNA assay kit (Invitrogen Life Technologies). DNA products were treated with Exo SAP-IT (USB Corp., Cleveland, $\mathrm{OH}$ ), using $2 \mu \mathrm{l}$ for every $5 \mu \mathrm{l}$ of DNA product to remove remaining dNTP and primers. Premixed sample templates consisted of 10 to $15 \mathrm{ng}$ of template, $8 \mathrm{pmol}$ of forward primers, and PCR-grade water added for a total volume of $15 \mu l$, and were sent

Table 1. (continued from preceding page)

\begin{tabular}{|c|c|c|c|c|c|}
\hline \multirow[b]{2}{*}{ Species, isolate ${ }^{b}$} & \multirow[b]{2}{*}{ Field code $\mathrm{e}^{\mathrm{c}}$} & \multirow[b]{2}{*}{ Baiting method ${ }^{d}$} & \multicolumn{3}{|c|}{ ITS rDNA GenBank submissiona } \\
\hline & & & Homology (\%) & Closest matching accession & $\overline{\text { Submitted sequence }}$ \\
\hline \multicolumn{6}{|c|}{ P. irregulare complex } \\
\hline B2-44 & 24 & Grass leaves & 98 & AY598702.2 & $\ldots$ \\
\hline B1-19 & 9 & Grass leaves & 99 & AY598702.2 & KP862949 \\
\hline B1-14 & 26 & Grass leaves & 99 & AY598702.2 & KP862950 \\
\hline B1-22 & 21 & Grass leaves & 99 & HQ643642.1 & $\ldots$ \\
\hline B2-43 & 31 & Grass leaves & 99 & HQ643596.1 & $\ldots$ \\
\hline \multicolumn{6}{|l|}{ P. kashmirense } \\
\hline B3-89 & 36 & Grass leaves & 99 & HQ643671.2 & $\ldots$ \\
\hline B1-13 & 33 & Grass leaves & 99 & HQ643671.2 & KP862951 \\
\hline B3-93 & 33 & Grass leaves & 100 & HQ643671.2 & KP862952 \\
\hline B $10-27$ & 33 & Corn & 100 & HQ643671.2 & $\ldots$ \\
\hline B1-30 & 5 & Grass leaves & 99 & HQ643671.2 & $\ldots$ \\
\hline \multicolumn{6}{|l|}{ P. middletonii } \\
\hline B3-60 & 15 & Grass leaves & 99 & AY598640.1 & KP862953 \\
\hline B5-63 & 17 & Grass leaves & 99 & AY598640.1 & $\ldots$ \\
\hline B5-61 & 16 & Grass leaves & 96 & AY598640.1 & $\ldots$ \\
\hline B1-15 & 37 & Grass leaves & 99 & AY598640.1 & $\ldots$ \\
\hline B3-68 & 30 & Grass leaves & 99 & AY598640.1 & KP862954 \\
\hline B4-35 & 30 & Grass leaves & 99 & AY598640.1 & $\ldots$ \\
\hline \multicolumn{6}{|l|}{ P. oligandrum } \\
\hline B3-77 & 8 & Grass leaves & 99 & AY598618.2 & KP862955 \\
\hline B3-64 & 3 & Grass leaves & 100 & AY598618.2 & KP862956 \\
\hline B4-16 & 8 & Grass leaves & 99 & AY598618.2 & $\ldots$ \\
\hline \multicolumn{6}{|l|}{ P. sylvaticum } \\
\hline B12-148 & 4 & Corn & 99 & AY598645.2 & KP862957 \\
\hline B12-151 & 4 & Corn & 99 & HQ643848.1 & KP862958 \\
\hline B12-147 & 4 & Corn & 99 & AY598645.2 & $\ldots$ \\
\hline \multicolumn{6}{|l|}{ P. torulosum } \\
\hline B4-1 & 21 & Grass leaves & 99 & AY598624.2 & $\ldots$ \\
\hline B1-37 & 27 & Grass leaves & 100 & AY598624.2 & $\ldots$ \\
\hline B1-11 & 11 & Grass leaves & 100 & AY598624.2 & $\ldots$ \\
\hline B1-5 & 36 & Grass leaves & 99 & AY598624.2 & $\ldots$ \\
\hline B3-72 & 4 & Grass leaves & 100 & AY598624.2 & KP862959 \\
\hline B4-20 & 15 & Grass leaves & 100 & AY598624.2 & $\ldots$ \\
\hline B1-24 & 6 & Grass leaves & 99 & AY598624.2 & $\ldots$ \\
\hline B3-70 & 35 & Grass leaves & 100 & AY598624.2 & KP862960 \\
\hline B4-25 & 4 & Grass leaves & 100 & AY598624.2 & $\ldots$ \\
\hline B8-113 & 32 & Grass leaves & 100 & AY598657.2 & KP862961 \\
\hline \multicolumn{6}{|c|}{ P. ultimum var. ultimum } \\
\hline B2-42 & 22 & Grass leaves & 99 & AY598657.2 & $\ldots$ \\
\hline B2-42 & 22 & Grass leaves & 99 & AY598657.2 & $\ldots$ \\
\hline B4-9 & 15 & Grass leaves & 100 & AY598657.2 & $\ldots$ \\
\hline B 1-1 & 30 & Grass leaves & 97 & AY598657.2 & $\ldots$ \\
\hline B8-96 & 19 & Grass leaves & 100 & AY598657.2 & KP862962 \\
\hline B9-141 & 19 & Grass leaves & 99 & AY598657.2 & $\ldots$ \\
\hline B3-82 & 12 & Grass leaves & 100 & AY598657.2 & $\ldots$ \\
\hline B1-23 & 37 & Grass leaves & 100 & AY598657.2 & $\ldots$ \\
\hline B3-73 & 2 & Grass leaves & 100 & AY598657.2 & $\ldots$ \\
\hline \multicolumn{6}{|l|}{ P. violae complex } \\
\hline B11-102 & 6 & Corn & 98 & AY598717.2 & $\ldots$ \\
\hline B11-77 & 37 & Pea & 98 & AY598717.2 & KP862963 \\
\hline B13-198 & 35 & Pea & 98 & AY598717.2 & $\ldots$ \\
\hline B12-139 & 35 & Corn & 97 & AY598717.2 & $\ldots$ \\
\hline B10-53 & 35 & Pea & 98 & AY598717.2 & $\ldots$ \\
\hline B13-194 & 30 & Pea & 98 & AY598717.2 & $\ldots$ \\
\hline B12-149 & 31 & Pea & 98 & AY598717.2 & $\ldots$ \\
\hline B12-145 & 31 & Pea & 98 & AY598717.2 & $\ldots$ \\
\hline B13-197 & 36 & Pea & 98 & AY598717.2 & KP862964 \\
\hline
\end{tabular}


to Elim Biopharmaceuticals, Inc. (Hayward, CA) for sequencing. Sequences were edited manually using Chromas Lite (Technelysium Pty. Ltd., South Brisbane, Australia) and compared with sequences in GenBank using the National Center for Biotechnology Information online BLAST tool. Sequences from the study of Lévesque and De Cock (2004) were used for species identification based on sequence similarity. For species described subsequent to that study, sequences from the study by Robideau et al. (2011) were used to confirm species identity based on 97 to $100 \%$ ITS sequence homology (Table 1). The sequences of 31 isolates, representing 2 isolates of each species identified and the single isolate of Pythium camurandrum identified, were deposited in GenBank as accession numbers KP862934 to KP862964 (Table 1).

Soil Pythium DNA-CFU regression curves. Pathogenicity tests of up to nine isolates of each of the Pythium spp. detected in this survey demonstrated that the three most prevalent pathogenic species were $P$. abappressorium, $P$. irregulare complex, and $P$. ultimum var. ultimum (data not shown) (Alcala 2013). To examine the relationship of DNA concentration (femtograms per gram of soil) with inoculum potential (CFU per gram of soil), a soil-CFU standard curve was developed for each of the three prevalent species. To prepare infested soil for each of the three prevalent Pythium spp., a soil sample from each of three fields representing the northern (field 14), central (field 20), and southern (field 36) regions of the Columbia Basin was steam pasteurized for $2 \mathrm{~h}$ at $70^{\circ} \mathrm{C}$, dried for 3 to 5 days, sieved (1-mm-diameter pore size) to remove plant debris, and crushed using a marble rolling pin. Inoculum of each of $P$. ultimum var. ultimum isolate $030141, P$. irregulare complex isolate B1-22, and $P$. abappressorium isolate B11-111 was produced using a mixture of ground oatmeal and steam-pasteurized soil from the three fields. Ground oatmeal (Quaker Oats Brand, Chicago) was mixed with the soil ( $1 \%$ by weight) using a PK Blendmaster soil blender (Patterson-Kelley Co., division of Harsco Corp., East Stroudsberg, PA) for $10 \mathrm{~min}$, with deionized water (15\% wt/wt) added slowly through a funneled hose attached to the blender during the last $5 \mathrm{~min}$ of mixing. Approximately $400 \mathrm{~g}$ or $1 \mathrm{~kg}$ of soil was placed in a 1-liter Kerr Mason jar or a 3.8-liter high-density polyethylene milk jug, respectively. The Mason jars were each covered with an autoclavable plastic lid typically used for mushroom spawn (Fungi Imperfecti, Olympia, WA), with a 1.3-cm-diameter hole drilled into the lid and a 70-mm-diameter synthetic filter disk (Fungi Imperfecti) placed beneath the lid. The milk jugs were each sealed with an autoclaved, 3.8-cm-diameter foam plug (VWR, Baltimore, MD) that was covered with two layers of aluminum foil. The jars or jugs of soil-oatmeal mix were autoclaved at $1.1 \mathrm{~kg} / \mathrm{cm}^{2}$ and $121^{\circ} \mathrm{C}$ for $50 \mathrm{~min}$, cooled for $24 \mathrm{~h}$, and autoclaved a second time using the same conditions. A $10-$ or $20-\mathrm{ml}$ volume of sterilized, distilled water was added to each jar or jug, respectively, and left overnight prior to inoculation with the appropriate Pythium isolate. A mycelial mat of a 5- to 7-day-old culture of the Pythium isolate grown in PDB was used to inoculate the soil-oatmeal. The inoculated jars or jugs for each Pythium sp. were stored in the dark at ambient temperature $\left(22 \pm 2^{\circ} \mathrm{C}\right)$ for 3 weeks, and shaken manually every 3 days to facilitate thorough colonization of the soil-oatmeal mix.

The inoculum concentration of each soil inoculated with each Pythium sp. was then quantified by dilution plating. Each jar or jug was shaken vigorously to mix the inoculum, and a 10-g sample was added to $100 \mathrm{ml}$ of sloppy agar ( $0.1 \% \mathrm{WA})$ and placed on a platform rotary shaker (Innova 2100; New Brunswick Scientific, Enfield, CT) for $10 \mathrm{~min}$ at $250 \mathrm{rpm}$. Fivefold dilutions were prepared, and three $0.5-\mathrm{ml}$ aliquots of each dilution were each spread on the surface of a WA plate. The plates were incubated at room temperature, and colonies counted after 24,30 , and $36 \mathrm{~h}$ to calculate CFU per gram of soil. Dilutions of each of the infested soils to target concentrations of $5,10,50,100,500$, and $1,000 \mathrm{CFU} / \mathrm{g}$ of soil were prepared to represent Pythium population densities reported for soils surveyed previously in eastern Washington (Cook 2002; Schroeder et al. 2006).

Three 500-mg soil samples of each field-Pythium spp. combination were used for DNA extraction for each of the soil dilutions with the Ultraclean Soil DNA isolation kit following the manufacturer's recommended protocol, with the modifications described below. A subsample of $1 \mathrm{~g}$ of soil was also used from each soil dilution to verify, by dilution plating, the viable Pythium concentration (CFU per gram of soil). The total DNA extracted/soil dilution was used in a real-time PCR assay with the appropriate species-specific primer for each Pythium sp. following the protocol described below. Regression analyses were calculated using Sigma Plot (version 11; Systat, San Jose, CA) to examine the relationship between target DNA concentration detected with the real-time quantitative PCR assay and pathogen population recovered from the infested soil (CFU per gram of soil) for each Pythium sp.

The CFU per gram of soil quantified after preparing each dilution series revealed a greater concentration of each Pythium sp. than the targeted range of 5 to 1,000 CFU/g of soil (see Results). Therefore, a repeat experiment was carried out to obtain an inoculum concentration range closer to the targeted range of $\leq 1,000$ $\mathrm{CFU} / \mathrm{g}$ of soil, using soil from one field (field 36). Soil dilution series for each Pythium sp. were prepared similarly with a target 5 to $1,000 \mathrm{CFU} / \mathrm{g}$ of soil. Total DNA was extracted as described above, followed by the real-time quantitative PCR assays. A 1-g subsample from each soil dilution was used for soil dilution plating on PSM agar to determine CFU per gram of soil for each dilution.

Quantification of Pythium spp. using real-time quantitative PCR assays. A quantitative, real-time PCR assay was used to detect and quantify inoculum of each of the three most prevalent and pathogenic Pythium spp. detected in the survey. Each field was represented by a subsample of soil from each of the four transects sampled, with each of the four subsamples considered a replicate for that field in each of the real-time PCR assays. The CFU per gram of soil for each field was calculated based on the regression equations developed above. DNA was extracted from 500 to $510 \mathrm{mg}$ of soil/transect/field using the Ultraclean Soil DNA isolation kit (Mo-Bio Laboratories, Carlsbad, CA) following the manufacturer's recommended procedure, with modifications. The samples were processed with an FP-24 cell disruptor (MP Biomedicals) for $45 \mathrm{~s}$ at speed 5 (Schroeder et al. 2006). Washed, 10\% insoluble polyvinylpolypyrrolidone was added after eluting the DNA from each spin column to help remove potential PCR inhibitors (Zhou et al. 1996). The DNA extract from each sample was used to quantify the three primary Pythium spp. using cartridge-purified, species-specific primer pairs and SYBR Green real-time PCR assays, as described by Schroeder et al. (2006).

For the quantitative PCR assay for each species, a $20-\mu 1$ reaction was prepared in a LightCycler 96 plate (Roche Applied Sciences, Indianapolis, IN) that included $12 \mu \mathrm{l}$ of PCR-grade water, $4 \mathrm{mM} \mathrm{MgCl}_{2}$, 8 pmol of each of the forward and reverse primers, $2 \mu l$ of LightCycler Fast Start DNA Master SYBR Green I (Roche Applied Science), and $2 \mu l$ of DNA extract. Each real-time PCR assay was completed in a LightCycler 480 thermal cycler (Roche Applied Science) as follows: $10 \mathrm{~min}$ of initial denaturation at $95^{\circ} \mathrm{C}$, followed by 50 cycles of $10 \mathrm{~s}$ at $95^{\circ} \mathrm{C}, 15 \mathrm{~s}$ at $70^{\circ} \mathrm{C}$, and $30 \mathrm{~s}$ at $72^{\circ} \mathrm{C}$. Melting curves were then generated by increasing the temperature to $95^{\circ} \mathrm{C}$ for $5 \mathrm{~s}$, decreasing to $65^{\circ} \mathrm{C}$ for $1 \mathrm{~min}$, and ramping up the temperature by $0.1^{\circ} \mathrm{C} / \mathrm{s}$ to $95^{\circ} \mathrm{C}$ with continuous measurement of fluorescence. Data were analyzed with the LightCycler 480 software using the second derivative maximum analysis, and compared with the standard curve using a 1-ng standardized DNA concentration for each species with DNA extracted from mycelium of P. ultimum var. ultimum isolate 030141, $P$. irregulare complex isolate 0900101 , and $P$. abappressorium isolate 020162 .

Statistical analyses. Regression analyses were calculated to examine the relationship between DNA concentration detected and CFU per gram of soil for each of the three Pythium spp. in the soils inoculated with these species. In addition, Pearson's correlation coefficients were calculated between soil properties measured-that is, macronutrients $\left(\mathrm{NO}_{3}-\mathrm{N}, \mathrm{NH}_{4}-\mathrm{N}, \mathrm{P}\right.$, and $\left.\mathrm{K}\right)$, micronutrients $(\mathrm{Ca}$, $\mathrm{Mg}, \mathrm{S}, \mathrm{B}, \mathrm{Zn}, \mathrm{Mn}, \mathrm{Cu}$, and $\mathrm{Fe}$ ), organic matter, $\mathrm{pH}$, and electrolytic conductivity - and the amount of DNA quantified for each of the 
three prevalent Pythium spp. in each of the 37 fields surveyed, to assess which soil properties were most significantly associated with inoculum concentrations of the three prevalent Pythium spp.

\section{Results}

Fields surveyed. Of the 305 Pythium isolates obtained from soils of the 37 fields surveyed, 41,17 , and $42 \%$ were from the northern, central, and southern regions of the Columbia Basin, respectively (Table 2). This may reflect the number of fields surveyed from each region (17, 5, and 15, respectively). Identification of 264 of the 305 isolates to species level by sequencing the ITS rDNA indicated the presence of 16 Pythium spp. (Tables 1 and 2), of which 13 species were detected in the 17 fields from the northern region, 9 species in the 5 fields from the central region, and 13 species in the 15 fields from the southern region. P. ultimum var. ultimum isolates made up $24.6 \%$ of all isolates, followed by $P$. torulosum at $18.7 \%$ and the P. irregulare complex at $14.8 \%$ (Table 2). A single isolate of $P$. camurandrum $(0.3 \%)$ was obtained from only 1 of the 37 fields. The incidence of other species isolated ranged from $1 \%$ (P. aristosporum, P. apiculatum, $P$. catenulatum, and P. oligandrum) to $4.9 \%$ (P. abappressorium) (Table 2). P. ultimum var. ultimum, $P$. torulosum, the $P$. irregulare complex, $P$. abappressorium, and $P$. middletonii were baited from $86,65,38,24$, and $24 \%$ of the 37 fields, respectively (Fig. 1). The other 10 species were detected in 5 to $22 \%$ of the fields (Fig. 1). The isolates of P. apiculatum, $P$. carolinianum, and $P$. oligandrum were obtained only from fields in the northern region, and P. camurandrum was present only in one field in the south of the Columbia Basin (Table 2). The composition of Pythium spp. isolated varied among the 37 fields surveyed. At least three Pythium spp. were isolated from $43 \%$ of the fields, in one field as many as seven species were isolated, and in one field a single species was isolated (data not shown). Of the 305 isolates baited, 41 were not identified to species because of failure to amplify and sequence the ITS rDNA.

Soil Pythium DNA-CFU regression analyses. The standard curves for the real-time quantitative PCR reactions had an efficiency \pm standard deviation (coefficient of determination $\left[R^{2}\right]$ ) of $93.0 \pm$ $0.08 \%$ (0.996), $90.4 \pm 0.12 \%$ (0.998), and $89.7 \pm 0.11 \%$ (1.000) for $P$. abappressorium, the $P$. irregulare complex, and $P$. ultimum var. ultimum, respectively (K. L. Schroeder, unpublished data). For the soils, a significant linear regression relationship $(P<$ 0.0001 ) of DNA concentration versus CFU per gram of soil detected by soil dilution plating was calculated for each of the three predominant pathogenic Pythium spp. inoculated into steam-pasteurized soil sampled from 3 of the 37 fields surveyed (Fig. 2). The $R^{2}$ ranged from 0.887 to 0.972 , with a comparable slope for the three Pythium spp. The greater the soil dilution (lower CFU per gram of soil) for each Pythium sp. in each soil, the greater the variability in DNA concentration detected. For this reason, results for the least concentrated soil (greatest dilution) were removed from the analyses to satisfy the assumption of equal variances among soil dilutions.

When soil assays were repeated using soil from a single field (field 36) that was steam-pasteurized and then inoculated separately with each of the three Pythium spp., starting with a lower inoculum concentration, significant differences $(P<0.0001)$ were observed in the amount of DNA detected (femtograms per gram of soil) by real-time quantitative PCR assay among soil dilutions. A similar significant linear relationship was detected between CFU per gram of soil and DNA concentration detected by real-time quantitative PCR assay for each Pythium sp. $(P<0.0001$ for all three species, with $R^{2}=0.921,0.799$, and 0.954 for $P$. abappressorium, the $P$. irregulare complex, and P. ultimum var. ultimum, respectively; Fig. 2C, F, and I, respectively). These results confirmed the linear increase in DNA concentration with increasing CFU per gram of soil, and repeatability of the real-time quantitative PCR assays. DNA detection was highly variable at the lowest inoculum concentration of $5 \mathrm{CFU} / \mathrm{g}$ of soil, and results were most variable for the $P$. irregulare complex among the repeated soil assays (Fig. 2F).

Regression analyses for each Pythium sp. using pooled standard curve data for soil from the three fields showed similar positive linear relationships $(P<0.0001)$ of DNA concentration detected versus Pythium population (CFU per gram of soil), with $R^{2}=0.976$ for $P$. abappressorium, 0.979 for the $P$. irregulare complex, and 0.974 for $P$. ultimum var. ultimum (Supplementary Fig. S1). The regression equations from standard curves pooled across the three soils for each of the three Pythium spp. were used to estimate the CFU per gram of soil from each of the 37 organic fields surveyed using the DNA concentration detected with the real-time quantitative PCR assays (Table 3). The levels of DNA detected for P. abappressorium were below the quantifiable limit $(<1,000 \mathrm{CFU} / \mathrm{g}$ of soil) that could be estimated accurately with the regression equation for this species (Fig. 2A, B, and C; Table 3). The inoculum density of the $P$. irregulare complex estimated with the regression equation for the 37 fields ranged from 0 to $264 \pm 115 \mathrm{CFU} / \mathrm{g}$ of soil, and $25 \pm 0$ to $264 \pm$ $115 \mathrm{CFU} / \mathrm{g}$ of soil in those fields in which the species was detected (Table 3). The inoculum density of $P$. ultimum var. ultimum estimated for soil from the 37 fields ranged from 0 to $322 \pm 32 \mathrm{CFU} / \mathrm{g}$ of soil, and $14 \pm 3$ to $322 \pm 32 \mathrm{CFU} / \mathrm{g}$ of soil in the fields in which this organism was detected (Table 3). For 5 and 14 of the 37 fields, DNA levels of the $P$. irregulare complex and $P$. ultimum var. ultimum, respectively, were below the quantifiable limit that could be estimated accurately using the regression equations for these species (Table 3).

Quantification of Pythium spp. in the 37 fields using real-time PCR assays. Of the three predominant pathogenic Pythium spp. detected in the 37 fields surveyed, $P$. ultimum var. ultimum was detected in $100 \%$ of the fields using a real-time quantitative PCR assay at DNA concentrations ranging from $42 \pm 26$ (mean \pm standard error) to $18,698 \pm 1,880 \mathrm{fg} / \mathrm{g}$ of soil (Table 3 ). Overall, $30 \%$ of the fields had $\geq 2,000 \mathrm{fg}, 62 \%$ had 200 to $1,999 \mathrm{fg}$, and $8 \%$ had $<200 \mathrm{fg}$ of DNA of P. ultimum var. ultimum per gram of soil (Table 3). In contrast, $P$. ultimum var. ultimum was recovered from only $86 \%$

Table 2. Prevalence of Pythium spp. isolated from soil sampled from 37 certified organic fields in the Columbia Basin of central Washington in 2009

\begin{tabular}{|c|c|c|c|c|c|}
\hline \multirow[b]{2}{*}{ Pythium spp. ${ }^{\text {b }}$} & \multicolumn{4}{|c|}{$\begin{array}{l}\text { Number of isolates collected/species } \\
\text { for each region in the Columbia Basin }\end{array}$} & \multirow[b]{2}{*}{ Species $(\%)^{\mathrm{c}}$} \\
\hline & Northern & Central & Southern & Total & \\
\hline $\begin{array}{l}\text { P. ultimum var. } \\
\text { ultimum }\end{array}$ & 36 & 18 & 21 & 75 & 24.6 \\
\hline P. torulosum & 21 & 8 & 28 & 57 & 18.7 \\
\hline $\begin{array}{l}\text { P. irregulare } \\
\text { complex }\end{array}$ & 6 & 9 & 30 & 45 & 14.8 \\
\hline P. abappressorium & 9 & 4 & 2 & 15 & 4.9 \\
\hline P. adhaerens & 5 & 0 & 8 & 13 & 4.3 \\
\hline P. middletonii & 8 & 2 & 3 & 13 & 4.3 \\
\hline P. dissotocum & 4 & 3 & 3 & 10 & 3.3 \\
\hline P. violae complex & 1 & 1 & 8 & 10 & 3.3 \\
\hline P. kashmirense & 0 & 1 & 4 & 5 & 1.6 \\
\hline P. carolinianum & 4 & 0 & 0 & 4 & 1.3 \\
\hline P. sylvaticum & 0 & 3 & 1 & 4 & 1.3 \\
\hline P. aristosporum & 1 & 0 & 2 & 3 & 1.0 \\
\hline P. apiculatum & 3 & 0 & 0 & 3 & 1.0 \\
\hline P. catenulatum & 1 & 0 & 2 & 3 & 1.0 \\
\hline P. oligandrum & 3 & 0 & 0 & 3 & 1.0 \\
\hline P. camurandrum & 0 & 0 & 1 & 1 & 0.3 \\
\hline Not identified ${ }^{\mathrm{d}}$ & 22 & 3 & 16 & 41 & 13.4 \\
\hline Total $(\%)^{\mathrm{e}}$ & $124(41)$ & $52(17)$ & $129(42)$ & 305 & $\ldots$ \\
\hline
\end{tabular}

${ }^{a}$ Details of the 37 fields, regions of the Columbia Basin, and sampling protocol are described in the text and in Supplementary Table S1.

b Pythium spp. isolated from soils sampled from the 37 certified organic fields and identified to species by sequencing the internal transcribed spacer (ITS) region of the ribosomal DNA (rDNA) using universal eukaryotic primers as described by Bakkeren et al. (2000), and Paulitz and Adams (2003).

c Percentage of the total 305 isolates baited that comprised each of the 16 Pythium spp.

${ }^{d}$ Of 305 isolates obtained from the 37 fields, 41 were not identified to species because of failure to amplify and sequence the ITS rDNA.

e Number in parentheses indicates percentage of the 305 isolates. 
of the fields with the grass leaf baiting method (Table 1; Fig. 1). Interestingly, in the five fields where this species was not recovered by baiting, considerable DNA concentrations $(1,112 \pm 628,1,678 \pm$ 994, $338 \pm 196,238 \pm 168$, and 2,108 $\pm 1,234 \mathrm{fg} / \mathrm{g}$ of soil) were detected in soil samples by real-time quantitative PCR assay (i.e., at greater densities than the fields from which this species was baited successfully; Table 3 ).

Soil from $92 \%$ of the 37 fields tested positive for P. abappressorium using the real-time quantitative PCR assay (Table 3), whereas this species was recovered from only $24 \%$ of the fields with the baiting method (Fig. 1). There were five fields in which DNA of $P$. abappressorium was detected at concentrations below the quantifiable limit (Table 3). The amount of DNA detected for this species in 29 of the fields was much less than that of $P$. ultimum var. ultimum, with DNA of $P$. abappressorium at $4 \pm 2$ to $226 \pm 134 \mathrm{fg} / \mathrm{g}$ of soil. Of the $37 \mathrm{fields}, 16 \%$ had DNA of $P$. abappressorium at $>100 \mathrm{fg} / \mathrm{g}$ of soil detected, $62 \%$ had $<100 \mathrm{fg} / \mathrm{g}$ of soil, and the remaining $22 \%$ of the fields had DNA levels below the quantifiable limit or not detected (Table 3).

DNA of isolates of the P. irregulare complex was detected in 57\% of the 37 fields using the real-time quantitative PCR assay (Table 3), in contrast to only $38 \%$ of the fields that tested positive for this species complex by the baiting method (Fig. 1). The amount of DNA detected of this species complex ranged from $14 \pm 4$ to $760 \pm 296 \mathrm{fg} / \mathrm{g}$ of soil; however, DNA of the $P$. irregulare complex was detected from only one or two of the four replicate soil samples tested from $45.9 \%$ of the fields (Table 3). For this species complex, $32.4 \%$ of the fields had DNA at $<200 \mathrm{fg} / \mathrm{g}$ of soil, $24.3 \% \mathrm{had}>200 \mathrm{fg} / \mathrm{g}$ of soil, and the remaining $43.2 \%$ of the fields did not test positive (Table 3 ).

Correlation analyses for the soil properties measured with the amount of DNA detected for each of the three Pythium spp. in the 37 organic fields revealed the most significant positive correlations of $P$. abappressorium DNA concentration with four soil properties: available levels of $\mathrm{Mn}(r=$ 0.424 at $P=0.009), \mathrm{Mg}(r=0.386$ at $P=0.018)$, organic matter $(r=$ 0.321 at $P=0.053)$, and $\mathrm{NH}_{4}-\mathrm{N}(r=0.316$ at $P=0.057)$. For the $P$. irregulare complex, DNA concentration was correlated significantly with only one soil property, available Fe $(r=0.389$ at $P=0.017)$. No soil properties were correlated significantly with DNA concentration of P. ultimum var. ultimum (data not shown).

\section{Discussion}

A very different composition of 16 Pythium spp. dominated the 37 certified organic vegetable production fields surveyed in this study in the semiarid, irrigated Columbia Basin of central Washington in comparison with surveys by Paulitz and Adams (2003), which identified $P$. abappressorium, $P$. rostratum, and $P$. debaryanum (later identified by Schroeder et al. [2006] through sequencing and further morphological examination to be $P$. irregulare group IV) as the most prevalent species in wheat fields of eastern Washington, as well as studies on orchard soils in the Columbia Basin by Mazzola et al. (2002, 2009). Differences in soil moisture, temperature, and cropping systems among these distinct regions may affect the composition of Pythium spp. in each region. However, the Pythium community identified in orchard soils from the Columbia Basin by Mazzola et al. $(2002,2009)$ was more similar to that of the eastern Washington wheat system, which was most likely associated with the fact that $60 \%$ of the ground cover is grass in these orchard systems. Thus, differences in soil moisture and temperature may not be the driving force in differences observed between this organic vegetable field survey and the eastern Washington wheat survey.

In this organic field survey, at least three Pythium spp. were isolated by baiting from $43 \%$ of the fields, one field had as many as seven species isolated, and a single species was isolated from only one of the fields. This was expected based on other surveys for Pythium spp. in agricultural or forestry soils (Broders et al. 2007; Paulitz and Adams 2003; Weiland 2011). Based on the three baits used in this study, grass blades appeared to be very effective for detection of species such as those in the $P$. irregulare complex but not for other species (e.g., P. abappressorium, P. sylvaticum, and the $P$. violae complex). This potential association of different combinations of Pythium spp. among fields may complicate the development of effective disease management strategies because of potential variation in sensitivity of different species to production practices, fungicide applications, or environmental conditions (Broders et al. 2007), although relatively few of the species identified in this survey were highly virulent on pea in pathogenicity tests completed using cool, moist conditions typical of early spring planting in the Columbia Basin (data not shown) (Alcala 2013). Under the conditions of those tests, isolates of only 8 of the 16 Pythium spp. baited were pathogenic on the pea cultivar Tonic (Alcala 2013).

Isolates of $P$. abappressorium, the $P$. irregulare complex, and $P$. ultimum var. ultimum were the most prevalent of the pathogenic species detected in this survey (data not shown) (Alcala 2013). Therefore, a soil Pythium DNA-CFU regression curve was developed for each of the three primary pathogenic Pythium spp. in order

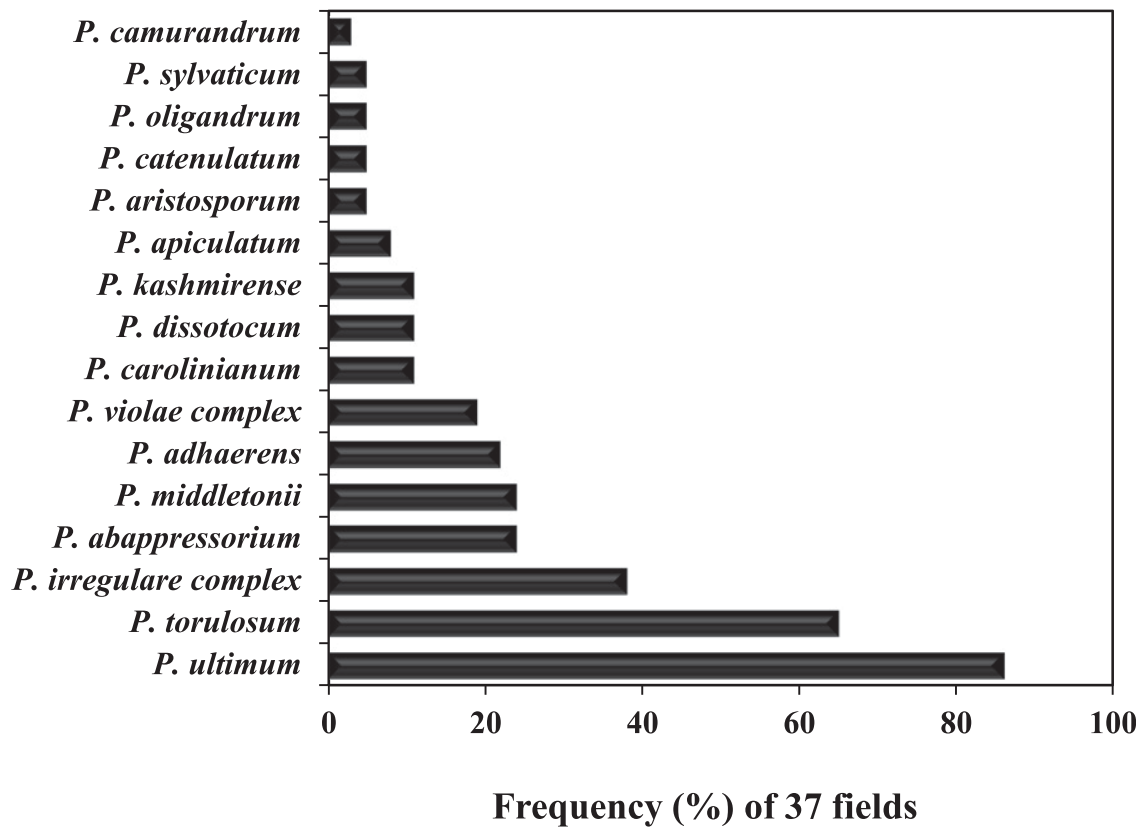

Fig. 1. Incidence (\%) of each of 16 Pythium spp. isolated from soil sampled from each of 37 certified organic fields in the Columbia Basin of Washington in 2009 using baiting methods as described in the text. 
to quantify these three pathogens in the 37 fields surveyed, using a quantitative real-time PCR assay for each species. When regression equations for the three Pythium spp. were used to estimate inoculum concentration of these species in the 37 organic fields based on DNA quantified with the real-time quantitative PCR assays, very few of the fields had inoculum levels similar to those reported by Cook et al. (1990) for wheat fields of the inland Pacific Northwest (200 CFU/g of soil). This suggests a need to investigate further whether inoculum densities detected in certified organic fields of the Columbia Basin for these three Pythium spp. could lead to significant damping-off in pea and other crops during spring planting conditions. The regression equation developed for $P$. ultimum var. ultimum estimated inoculum concentrations of 1.6 CFU per 100 fg of DNA per gram of soil, which is similar to that detected by K. L. Schroeder and T. C. Paulitz in eastern Washington wheat fields (unpublished data); that is, Pythium DNA at 0 to $100 \mathrm{fg} /$ propagule/g of soil using inoculated soil samples. However, the equation used to estimate inoculum concentration was developed using pasteurized soil inoculated with each of the Pythium spp., and has not been validated for field soil samples with natural Pythium populations in the presence of other soil microflora that may affect survival and inoculum potential of Pythium spp. in soils (Martin and Loper 1999).

P. ultimum var. ultimum was detected in all 37 fields with the realtime quantitative PCR assay at DNA concentrations generally greater than DNA levels detected for the two other prevalent, pathogenic species. P. abappressorium DNA was detected in $92 \%$ of the fields but at lower concentrations than that of $P$. ultimum var. ultimum, while $P$. irregulare complex DNA was detected in only $57 \%$ of the fields. The frequency of detection of these species in soils from the 37 fields using the real-time quantitative PCR assays was greater than the frequency of recovery by baiting with grass leaves and by pea or sweet corn seed planted in soil samples. Schroeder et al. (2006) used the same species-specific primer pairs for detecting the three Pythium spp. from fields in eastern Washington, and detected greater amounts of DNA of $P$. abappressorium and the $P$. irregulare complex from dry soil samples (e.g., 580 to $2,775 \mathrm{fg} / \mathrm{g}$ of soil for $P$. abappressorium in three fields, and $5,360 \mathrm{fg} / \mathrm{g}$ of soil for the $P$. irregulare complex in only one of six fields), and wet soil samples (680 to $6,065 \mathrm{fg} / \mathrm{g}$ of soil for P. abappressorium and 7,980 fg/g of soil for the $P$. irregulare complex) compared with what was detected in this study in organic soils from the Columbia Basin. In contrast, $P$. ultimum var. ultimum was detected frequently at greater amounts of DNA in the 37 organic fields in the Columbia Basin compared with wheat fields in eastern Washington, where the amount of DNA quantified was $<10 \mathrm{fg} /$ reaction (Schroeder et al. 2006).

Schroeder et al. (2006) reported that variation in the amount of Pythium DNA detected in eastern Washington soils increased greatly
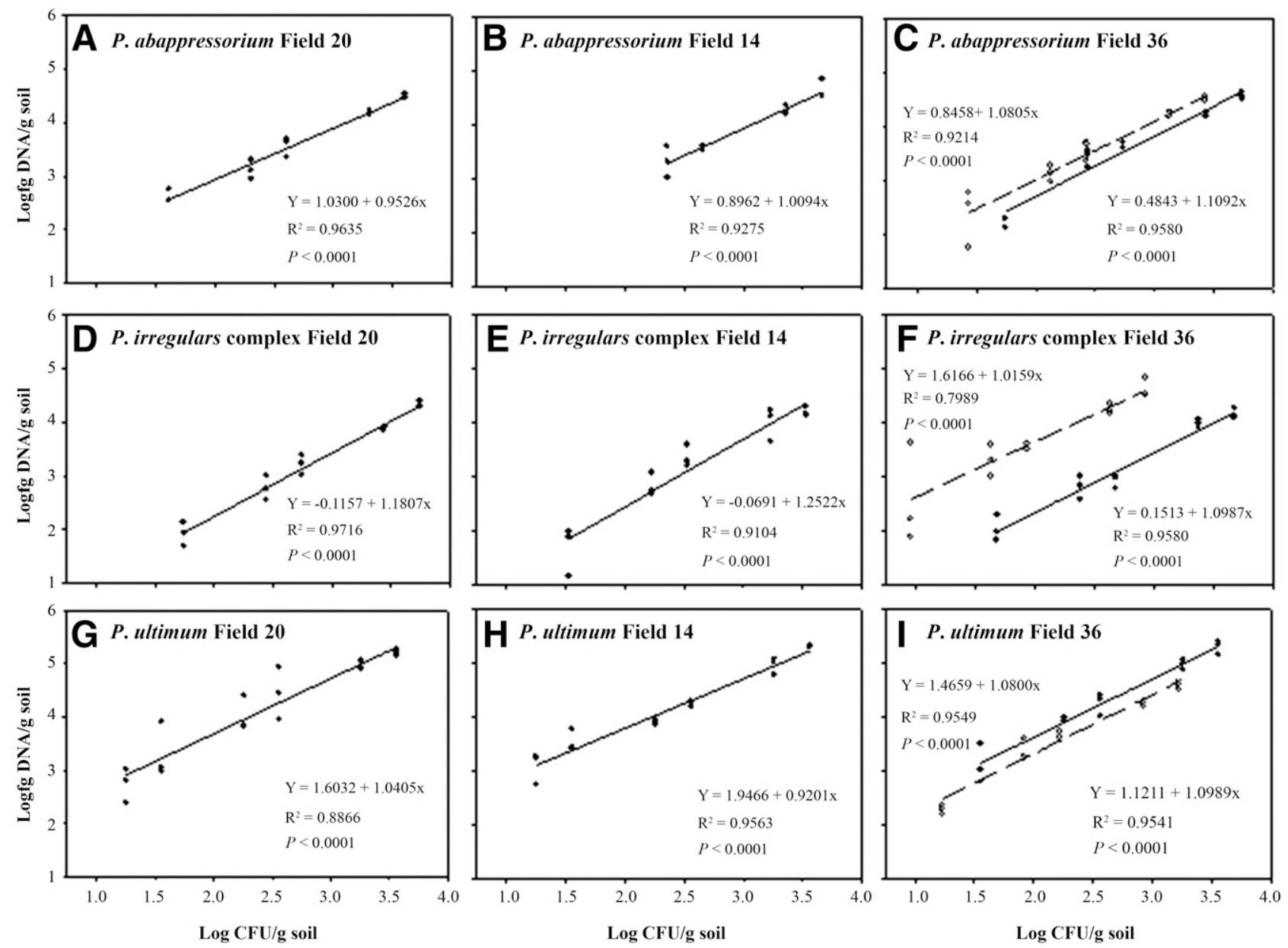

Fig. 2. Regression analyses of the soil population density (CFU per gram of soil) versus soil DNA concentration (femtograms per gram of soil) detected by real-time quantitative polymerase chain reaction (PCR) assays for each of $\mathbf{A}$ to $\mathbf{C}$, Pythium abappressorium; $\mathbf{D}$ to F, the $P$. irregulare complex; and $\mathbf{G}$ to $\mathbf{I}, P$. ultimum var. ultimum. Soil from each of three fields-field 20 (A, D, and G), field 14 (B, E, and H), and field 36 (C, F, and I) - was inoculated with each of the three Pythium spp. separately, then used in a soil dilution series to achieve populations ranging from 5 to $1,000 \mathrm{CFU} / \mathrm{g}$ of soil. The number of propagules (CFU per gram of soil) detected on a Pythium selective medium agar (Mircetich and Kraft 1973), however, was greater than the target range when quantified by dilution plating. Dashed lines in C, F, and I represent results of the regression analyses when assays were repeated using a lower target population range of the three Pythium spp. in soil from field 36 . Due to excessive variability in the amount of DNA detected across replicate samples at the greatest soil dilution (lowest CFU per gram of soil), data points for those dilutions were not included in the regression analyses to satisfy the assumption of equal variances. Each data point is the mean of three replicate soil DNA extractions tested with the real-time quantitative PCR assay using species-specific primers for each of the three Pythium spp., as described by Schroeder et al. (2006). $R^{2}=$ coefficient of determination, $P=$ probability of no significant regression relationship between the two variables, $Y=$ predicted log (femtograms of DNA per gram of soil), and $x=\log$ CFU per gram of soil. 
as the population of Pythium in the soil approached the detection limit of 10 to $100 \mathrm{fg} / \mathrm{g}$ of soil for the real-time quantitative PCR assay used, although $P$. abappressorium was detected at concentrations as low as $4 \mathrm{fg} / \mathrm{g}$ of soil in that survey. Overall, results of the real-time quantitative PCR assays in this study in central Washington were consistent with those of other studies in which real-time quantitative PCR assays were used to detect and quantify specific pathogens in soil (Li et al. 2010; Schroeder et al. 2006). The potential use of real-time quantitative PCR assays to detect and quantify Pythium spp. in soils with greater sensitivity than baiting methods has been documented (Li et al. 2010; Schroeder et al. 2006). However, such real-time quantitative PCR assays detect DNA of the target pathogens regardless of the viability of the propagules, which could account, in part, for the greater sensitivity with this method versus baiting. Furthermore, variability in the amount of DNA detected from the four soil transects assayed per field for each of the three Pythium spp. may reflect the aggregated distribution of Pythium in soils (Okubara et al. 2005). Although mixing 20 soil cores/transect should have addressed this to some degree, the very limited volume of soil from which DNA can be extracted using most DNA extraction kits is a major limitation to representative quantification of soilborne pathogens. However, several studies have demonstrated the ability to overcome this limitation by optimizing soil DNA extraction methods for samples of up to $500 \mathrm{~g}$ of soil (Brierley et al. 2009; Ophel-Keller et al. 2008).

Further investigations are needed to determine the inoculum concentrations at which growers typically experience significant losses from these Pythium spp. in pea and other crops, and to validate the regression equations developed in this study. If a consistent relationship between DNA concentration and CFU per gram of soil detected

Table 3. Quantification by real-time polymerase chain reaction (PCR) assays of three Pythium spp. pathogenic on pea and isolated from soil sampled from each of 37 certified organic fields in the Columbia Basin of Washington in 2009

\begin{tabular}{|c|c|c|c|c|c|c|c|c|c|c|}
\hline \multirow[b]{2}{*}{$\operatorname{Region}^{b}$} & \multirow[b]{2}{*}{ Field $\operatorname{code}^{c}$} & \multicolumn{3}{|c|}{ P. abappressorium } & \multicolumn{3}{|c|}{ P. irregulare complex } & \multicolumn{3}{|c|}{ P. ultimum var. ultimum } \\
\hline & & DNA $(f g)^{d}$ & $N^{\mathrm{e}}$ & Mean CFU' & DNA (fg) & $N$ & Mean CFU & DNA (fg) & $N$ & Mean CFU \\
\hline Northern & 1 & $62 \pm 30$ & 3 & BQL & $760 \pm 296$ & 4 & $264 \pm 115$ & $436 \pm 286$ & 4 & BQL \\
\hline Northern & 2 & $102 \pm 48$ & 4 & BQL & - & - & - & $918 \pm 558$ & 4 & $15 \pm 9$ \\
\hline Northern & 3 & $198 \pm 92$ & 4 & $\mathrm{BQL}$ & $262 \pm 10$ & 3 & $103 \pm 6$ & $1,662 \pm 1,148$ & 4 & $28 \pm 19$ \\
\hline Northern & 4 & $6 \pm 2$ & 4 & BQL & $148 \pm 20$ & 2 & $62 \pm 11$ & $2,114 \pm 1,178$ & 4 & $36 \pm 20$ \\
\hline Northern & 5 & BQL & - & BQL & $644 \pm 6$ & 2 & $228 \pm 4$ & $128 \pm 8$ & 4 & BQL \\
\hline Northern & 6 & $168 \pm 22$ & 4 & BQL & $206 \pm 4$ & 2 & $83 \pm 3$ & $832 \pm 192$ & 4 & $14 \pm 3$ \\
\hline Northern & 7 & $20 \pm 6$ & 4 & BQL & - & - & - & $2,864 \pm 822$ & 4 & $48 \pm 14$ \\
\hline Northern & 8 & $88 \pm 28$ & 4 & BQL & - & - & - & $430 \pm 244$ & 4 & BQL \\
\hline Northern & 9 & $52 \pm 52$ & 4 & $\mathrm{BQL}$ & - & - & - & $338 \pm 196$ & 4 & BQL \\
\hline Northern & 10 & $28 \pm 8$ & 4 & BQL & - & - & - & $1,322 \pm 208$ & 4 & $22 \pm 3$ \\
\hline Northern & 11 & $30 \pm 10$ & 3 & BQL & - & - & - & $362 \pm 152$ & 4 & BQL \\
\hline Northern & 12 & $58 \pm 42$ & 4 & BQL & $250 \pm 0$ & 1 & $99 \pm 0$ & $4,462 \pm 2,466$ & 4 & $76 \pm 42$ \\
\hline Northern & 13 & $44 \pm 22$ & 4 & BQL & - & - & - & $2,140 \pm 1,704$ & 4 & $36 \pm 29$ \\
\hline Northern & 14 & $12 \pm 6$ & 3 & BQL & - & - & - & $238 \pm 168$ & 4 & BQL \\
\hline Northern & 15 & $184 \pm 74$ & 4 & BQL & $54 \pm 0$ & 1 & $25 \pm 0$ & $1,986 \pm 796$ & 4 & $33 \pm 13$ \\
\hline Northern & 16 & $154 \pm 46$ & 4 & BQL & - & - & - & $18,698 \pm 1,880$ & 4 & $322 \pm 32$ \\
\hline Northern & 17 & $16 \pm 6$ & 3 & BQL & - & - & - & $5,956 \pm 904$ & 4 & $101 \pm 15$ \\
\hline Central & 18 & $66 \pm 20$ & 4 & BQL & $368 \pm 108$ & 4 & $139 \pm 47$ & $5,394 \pm 1,918$ & 4 & $92 \pm 32$ \\
\hline Central & 19 & $28 \pm 6$ & 4 & BQL & $330 \pm 104$ & 2 & $126 \pm 45$ & $3,020 \pm 814$ & 4 & $51 \pm 14$ \\
\hline Central & 20 & $24 \pm 12$ & 4 & BQL & $14 \pm 4$ & 2 & BQL & $1,678 \pm 994$ & 4 & $28 \pm 17$ \\
\hline Central & 21 & $34 \pm 20$ & 4 & BQL & $34 \pm 0$ & 1 & BQL & $5,546 \pm 2,102$ & 4 & $94 \pm 35$ \\
\hline Central & 22 & $226 \pm 134$ & 4 & BQL & - & - & - & $42 \pm 26$ & 4 & BQL \\
\hline Southern & 23 & BQL & 1 & BQL & $302 \pm 0$ & 1 & $117 \pm 0$ & $656 \pm 210$ & 4 & BQL \\
\hline Southern & 24 & BQL & 3 & BQL & $38 \pm 0$ & 1 & BQL & $6,808 \pm 6,182$ & 4 & $116 \pm 105$ \\
\hline Southern & 25 & BQL & 1 & BQL & $20 \pm 0$ & - & BQL & $498 \pm 238$ & 4 & BQL \\
\hline Southern & 26 & $18 \pm 14$ & 3 & BQL & - & - & - & $1,112 \pm 628$ & 4 & $19 \pm 10$ \\
\hline Southern & 27 & $10 \pm 6$ & 3 & BQL & $14 \pm 1$ & 2 & BQL & $232 \pm 52$ & 4 & BQL \\
\hline Southern & 28 & BQL & - & BQL & $74 \pm 34$ & 2 & $34 \pm 17$ & $138 \pm 28$ & 4 & BQL \\
\hline Southern & 29 & $4 \pm 2$ & 2 & BQL & $132 \pm 88$ & 2 & $56 \pm 39$ & $416 \pm 332$ & 4 & BQL \\
\hline Southern & 30 & - & - & BQL & $154 \pm 0$ & 1 & $64 \pm 0$ & $338 \pm 232$ & 4 & BQL \\
\hline Southern & 31 & $58 \pm 50$ & 4 & BQL & - & - & - & $1,542 \pm 886$ & 4 & $26 \pm 15$ \\
\hline Southern & 32 & - & - & BQL & $116 \pm 0$ & 1 & $50 \pm 0$ & $858 \pm 504$ & 4 & $14 \pm 8$ \\
\hline Southern & 33 & - & - & BQL & $136 \pm 0$ & 1 & $57 \pm 0$ & $1,990 \pm 920$ & 4 & $34 \pm 15$ \\
\hline Southern & 34 & $4 \pm 1$ & 2 & BQL & - & - & - & $1,314 \pm 792$ & 4 & $22 \pm 13$ \\
\hline Southern & 35 & $28 \pm 16$ & 4 & BQL & $222 \pm 0$ & 1 & $89 \pm 0$ & $2,108 \pm 1,234$ & 4 & $36 \pm 21$ \\
\hline Southern & 36 & $8 \pm 6$ & 2 & BQL & - & - & - & $1,058 \pm 826$ & 4 & $18 \pm 14$ \\
\hline Southern & 37 & $22 \pm 20$ & 2 & BQL & - & - & - & $352 \pm 162$ & 4 & BQL \\
\hline
\end{tabular}

a $\mathrm{BQL}=$ the species was detected by real-time quantitative PCR assay but the DNA concentration was below the quantifiable limit, and - indicates that soil was tested but DNA was not detected for that Pythium spp.

b Northern, central, and southern regions of the Columbia Basin are defined in the text.

c Field codes and details are described in Supplementary Table S1.

d DNA (fg) = mean \pm standard error of femtograms of DNA per gram of soil extracted and quantified from each of $N$ of the four samples assayed per field. Realtime quantitative PCR assays were completed using protocols described in the main text for each species, based on the methods of Schroeder et al. (2006).

e $N=$ number of soil samples assayed per field. Twenty soil cores were sampled in each of four transects/field, and samples were pooled within transects. Subsamples of $500 \mathrm{mg}$ were used for DNA extraction for the real-time quantitative PCR assays.

${ }^{\mathrm{f}}$ Mean CFU $=$ mean \pm standard error of CFU per gram of soil of each Pythium sp. estimated based on a regression equation developed by quantifying DNA in a soil dilution series using real-time quantitative PCR assays developed by Schroeder et al. (2006). Soil dilutions were prepared from pasteurized soil collected from a certified organic field in the Columbia Basin and then inoculated with each of the three Pythium spp. Inoculum concentration was quantified by dilution plating onto a Pythium selective agar medium (Mircetich and Kraft 1973). Regression analyses of DNA concentrations and CFU per gram of soil in the soil dilutions were analyzed using SigmaPlot (Version 11; Systat, San Jose, CA). 
on selective agar media can be established with naturally infested soil samples, DNA-based inoculum prediction using real-time quantitative PCR assays might provide a rapid and accurate way to predict the risk of damping-off. This will help with developing and implementing appropriate management tactics prior to planting, which could assist growers of organic crops who have limited management options for damping-off caused by Pythium spp. Ultimately, a multiplex PCR assay could be developed to detect and quantify multiple target Pythium spp. associated with damping-off in a single assay, which will increase the efficiency of DNA-based assessment of inoculum concentration and make it possible to assay a greater number of samples, thereby improving accuracy of results. Such an assay could provide a tool for risk assessment and timely application of control strategies to manage damping-off in organic production, and could be of similar value to conventionally grown crops highly susceptible to Pythium spp. However, even if such a diagnostic tool becomes available, the inoculum potential of a field for damping-off is a function not only of inoculum concentration at the time of planting and seedling establishment but also of the ability of different Pythium spp. to form zoospores, the mix of pathogenic and nonpathogenic species, and environmental and cultural practices, as demonstrated for soilborne plant pathogens in other studies (Gatch and du Toit 2015; Okubara et al. 2013).

\section{Acknowledgments}

We thank Washington organic vegetable grower-cooperators and processors, and B. Holmes (WSU Mount Vernon NWREC staff) and G. Coffman and T. McClure (USDA-ARS, Prosser, WA) for technical assistance.

\section{Literature Cited}

Abad, Z. G., Shew, H. D., and Lucas, L. T. 1994. Characterization and pathogenicity of Pythium species isolated from turfgrass with symptoms of root and crown rot in North Carolina. Phytopathology 84:913-921.

Agrios, G. N. 2005. Plant Pathology, 5th Ed. Academic Press, Inc., San Diego, CA.

Alcala, A. C. 2013. Management of damping-off caused by Pythium spp. in organic vegetable production in the Pacific Northwest. Ph.D. dissertation, Washington State University, Pullman.

Alcala, A. C., and du Toit, L. J. 2009. Management of damping-off in organic vegetable crops in the Pacific Northwest. Sustain. Pacific Northwest 7:5-7.

Augspurger, C. K. 2007. Host specificity of pathogenic Pythium species: Implications for tree species diversity. Biotropica 39:702-708.

Bakkeren, G., Kronstad, J. W., and Lévesque, C. A. 2000. Comparison of AFLP fingerprints and ITS sequences as phylogenetic markers in Ustilaginomycetes. Mycologia 92:510-521.

Brierley, J. L., Stewart, J. A., and Lees, A. K. 2009. Quantifying potato pathogen DNA in soil. Appl. Soil Ecol. 41:234-238.

Broders, K. D., Lipps, P. E., Paul, P. A., and Dorrance, A. E. 2007. Characterization of Pythium spp. associated with corn and soybean seed and seedling disease in Ohio. Plant Dis. 91:727-735.

Broders, K. D., Wallhead, M. W., Austin, G. D., Lipps, P. E., Paul, P. A., Mullen, R. W., and Dorrance, A. E. 2009. Association of soil chemical and physical properties with Pythium species diversity, community composition, and disease incidence. Phytopathology 99:957-967.

Campion, C., Massion, P., and Rouxel, F. 1997. Aggressiveness and production of cell wall degrading enzymes by Pythium violae, Pythium sulcatum and Pythium ultimum responsible for cavity spot on carrots. Eur. J. Plant Pathol. 103:725-735.

Chamswarng, C., and Cook, R. J. 1985. Identification and comparative pathogenicity of Pythium species from wheat roots and wheat field soils in the Pacific Northwest. Phytopathology 75:821-827.

Cook, R. J. 1992. Wheat root health management and environmental concern. Can. J. Plant Pathol. 14:76-85.

Cook, R. J. 2002. New insights into management of soilborne crop pathogens under direct seeding: Pythium. http://pnwsteep.wsu.edu/directseed/conf2k2/dsccook.htm

Cook, R. J., Chamswarng, C., and Tang, W. 1990. Influence of wheat chaff and tillage on Pythium populations and Pythium damage to wheat. Soil Biol. Biochem. 22: 939-947.

Cook, R. J., Sitton, J. W., and Haglund, W. A. 1987. Influence of soil treatments on growth and yield of wheat and implications for control of Pythium root rot. Phytopathology 77:1192-1198.

Gatch, E. W., and du Toit, L. J. 2015. A soil bioassay for predicting the risk of spinach Fusarium wilt. Plant Dis. 99:512-526.

Granatstein, D., and Kirby, E. 2010. First national survey of organic agriculture released. Sustaining Pacific Northwest 8:8-10.

Granatstein, D., Stone, A., Williams, C., Miles, C., Bezdicek, D., and Perillo, C. 2005. Organic farming research in the Pacific Northwest: Challenges, opportunities, and outlook. http://asi.ucdavis.edu/programs/sarep/publications/ ag-resources-enviro/compliancehandbook-organicfarmingresearch.pdf/ (accessed January 2016)
Hendrix, F. F., Jr., and Campbell, W. W. 1973. Pythiums as plant pathogens. Annu. Rev. Phytopathol. 11:77-98.

Hershman, D. E. 1986. Etiology of parsley damping-off and influence of temperature on disease development. Plant Dis. 70:927-930

Kirby, E., and Granatstein, D. 2009. Profile of organic crops in Washington State2008. Online publication. Washington State University Center for Sustaining Agriculture and Natural Resources. http://csanr.wsu.edu/publications/techreports/ Organic\%20Stats/WA_CertAcres_08.pdf

Kirby, E., and Granatstein, D. 2014. Certified organic acreage and sales in Washington State: 2013. Organic Trends series. Online Publication Center for Sustaining Agriculture and Natural Resources, Washington State University, Wenatchee. http://csanr.wsu.edu/wp-content/uploads/2014/05/WA_Crop-Tables_ 2005-13-final.pdf

Lévesque, C. A. 2001. Molecular methods for detection of plant pathogens-What is the future? Can. J. Plant Pathol. 24:333-336.

Lévesque, C. A., and De Cock, A. W. A. M. 2004. Molecular phylogeny and taxonomy of the genus Pythium. Mycol. Res. 108:1363-1383.

Li, M., Masako, S., Komatsu, T., Suga, H., and Kageyama, K. 2010. Development of a real-time PCR technique for the estimation of population density of Pythium intermedium in forest soils. Microbiol. Res. 165:695-705.

Mansour, N. S., Anderson, W., and Darell, T. J. 1984. Producing processing peas in the Pacific Northwest. Pac. Northwest Ext. Publ. 243. Washington State University, Pullman.

Martin, F. N. 1992. Pythium. Pages 39-49 in: Methods for Research on Soilborne Phytopathogenic Fungi. L. L. Singleton, J. D. Mihail, and C. M. Rush, eds. American Phytopathological Society, St. Paul, MN.

Martin, F. N., and Loper, J. E. 1999. Soilborne plant diseases caused by Pythium spp.: Ecology, epidemiology, and prospects for biological control. Crit. Rev. Plant Sci. 18:111-181.

Mazzola, M., Andrews, P. K., Reganold, J. P., and Lévesque, C. A. 2002. Frequency, virulence, and metalaxyl sensitivity of Pythium spp. isolated from apple roots under conventional and organic production systems. Plant Dis. 86:669-675.

Mazzola, M., Brown, J., Zhao, X., Izzo, A. D., and Fazio, G. 2009. Interaction of brassicaceous seed meal and apple rootstock on recovery of Pythium spp. and Pratylenchus penetrans from roots grown in replant soils. Plant Dis. 93: $51-57$

Miller, T., and Parker, R. 2006. Nightshade: Biology and control in the Pacific Northwest. Pac. Northwest Ext. Publ. 0588. Washington State University, Pullman.

Mircetich, S. M., and Kraft, J. M. 1973. Efficiency of various selective media in determining Pythium populations in soil. Mycopathol. Mycol. Appl. 50:151-161.

Nederhoff, E. 2000. Pythium only successful in stressed plants. Comm. Grower 55 41-42.

Okubara, P., Harrison, L. A., Gatch, E. W., Schroeder, K., Vandemark, G., and du Toit, L. J. 2013. Development and evaluation of a TaqMan real-time PCR assay for Fusarium oxysporum f. sp. spinaciae. Plant Dis. 97:927-937.

Okubara, P. A., Schroeder, K. L., and Paulitz, T. C. 2005. Real-time polymerase chain reaction: Applications to studies on soilborne pathogens. Can. J. Plant Pathol. 27:300-313

Ophel-Keller, K., McKay, A., Hartley, D., Herdina, and Curran, J. 2008 Development of a routine DNA-based testing service for soilborne disease in Australia. Australas. Plant Pathol. 37:243-253.

Oyarzun, P. J. 1993. Biossay to assess root rot in pea and effect of root rot on yield. Neth. J. Plant Pathol. 99:61-75

Park, D. 1963. The ecology of soilborne fungal disease. Annu. Rev. Phytopathol 1:241-258.

Paulitz, T. C., and Adams, K. 2003. Composition and distribution of Pythium communities in wheat fields in eastern Washington State. Phytopathology 93 : 867-873.

Rao, B., Schimitthenner, A. F., Caldwell, R., and Ellet, C. W. 1978. Prevalence and virulence of Pythium species associated with root rot of corn in poorly drained soils. Phytopathology 68:1557-1563.

Robideau, G. P., De Cock, A. W., Coffey, M. D., Voglmayr, H., Brouwer, H., Bala, K., Chitty, D. W., Desaulniers, N., Eggertson, Q. A., Gachon, C. M., Hu, C. H., Kupper, F. C., Rintoul, T. L., Sarhan, E., Verstappen, E. C., Zhang, Y., Bonants, P. J., Ristaino, J. B., and Lévesque, C. A. 2011. DNA barcoding of oomycetes with cytochrome $\mathrm{c}$ oxidase subunit I and internal transcribed spacer. Mol. Ecol. Resour. 11:1002-1011.

Schroeder, K. L., Okubara, P. A., Tambong, J. T., Lévesque, C. A., and Paulitz, T. C. 2006. Identification and quantification of pathogenic Pythium spp. from soils of eastern Washington using real-time polymerase chain reaction. Phytopathology 96:637-647.

Short, G. E., and Lacy, M. L. 1976. Carbohydrate exudation from pea seeds Effect of cultivar, seed age, seed color, and temperature. Phytopathology 66:182-187.

van der Plaats-Niterink, A. J. 1981. Monograph of the Genus Pythium. Studies in Mycology No. 21. Centraalbureau voor Schimmelculture, Baarn, The Netherlands.

Weiland, J. E. 2011. Influence of isolation method on recovery of Pythium species from forest nursery soils in Oregon and Washington. Plant Dis. 95:547-553.

Zhou, J., Bruns, M., and Tiedje, J. M. 1996. DNA recovery from soils of diverse composition. Appl. Environ. Microbiol. 62:316-322. 